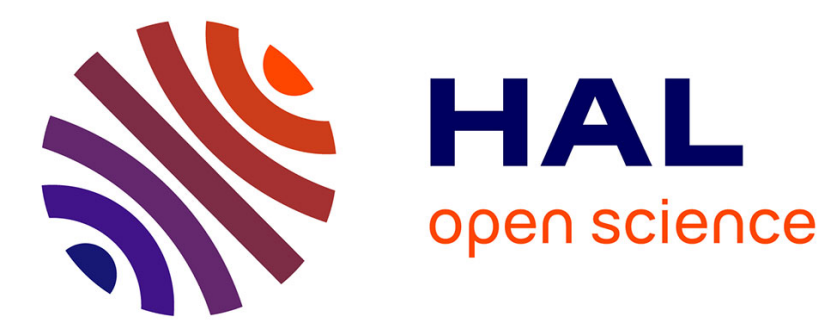

\title{
The Dole effect and its variations during the last 130,000 years as measured in the Vostok ice core
}

Michael Bender, Todd Sowers, Laurent Labeyrie

\section{To cite this version:}

Michael Bender, Todd Sowers, Laurent Labeyrie. The Dole effect and its variations during the last 130,000 years as measured in the Vostok ice core. Global Biogeochemical Cycles, 1994, 8 (3), pp.363376. 10.1029/94GB00724 . hal-03587354

\section{HAL Id: hal-03587354 https://hal.science/hal-03587354}

Submitted on 24 Feb 2022

HAL is a multi-disciplinary open access archive for the deposit and dissemination of scientific research documents, whether they are published or not. The documents may come from teaching and research institutions in France or abroad, or from public or private research centers.
L'archive ouverte pluridisciplinaire HAL, est destinée au dépôt et à la diffusion de documents scientifiques de niveau recherche, publiés ou non, émanant des établissements d'enseignement et de recherche français ou étrangers, des laboratoires publics ou privés. 


\title{
The Dole effect and its variations during the last 130,000 years as measured in the Vostok ice core
}

\author{
Michael Bender ${ }^{1}$ and Todd Sowers ${ }^{2}$ \\ Graduate School of Oceanography, University of Rhode Island, Kingston \\ Laurent Labeyrie \\ Centre des Faibles Radioactivites, Centre National de la Recherche Scientifique, Commissariat a L'Energie Atomique, \\ Gif-sur- Yvette, France
}

\begin{abstract}
We review the current understanding of the Dole effect (the observed difference between the $\delta^{18} \mathrm{O}$ of atmospheric $\mathrm{O}_{2}$ and that of seawater) and its causes, extend the record of variations in the Dole effect back to $130 \mathrm{kyr}$ before present using data on the $\delta^{18} \mathrm{O}$ of $\mathrm{O}_{2}$ obtained from studying the Vostok ice core (Sowers et al., 1993), and discuss the significance of temporal variations. The Dole effect reflects oxygen isotope fractionation during photosynthesis, respiration, and hydrologic processes (evaporation, precipitation, and evapotranspiration). Our best prediction of the present-day Dole effect, $+20.8 \%$, is considerably lower than the observed value, $+23.5 \%$, and we discuss possible causes of this discrepancy. During the past $130 \mathrm{kyr}$, the Dole effect has been $0.05 \%$ o lower than the present value, on average. The standard deviation of the Dole effect from the mean has been only $\pm 0.2 \%$, and the Dole effect is nearly unchanged between glacial maxima and interglacial periods. The small variability in the Dole effect suggests that relative rates of primary production in the land and marine realms have been relatively constant. Most periodic variability in the Dole effect is in the precession band, suggesting that changes in this global biogeochemical term reflects variations in low-latitude land hydrology and productivity or possibly variability in low-latitude oceanic productivity.
\end{abstract}

\section{Introduction}

Our understanding of the response of the biosphere to Pleistocene climate change is actually quite limited. For the terrestrial realm, our most detailed knowledge comes from extensive studies of pollen in sediments which record climate during and after the last glacial termination [e. g., COHMAP, 1988]. Pollen data for earlier times are extremely informative but geographically restricted. In the marine realm, the most ambitious attempts to understand the response of the biosphere to climate have focused on studies of primary productivity in the past inferred from two proxy indicators: organic carbon accumulation rates [e. g., Sarnthein et al., 1988, 1992] and foraminiferal taxonomy [Mix, 1989a, b]. Paleoproductivity estimates made from many other proxies have enlivened the discussion with respect to specific areas of the ocean.

Proxy studies of the response of the terrestrial and marine biosphere are limited in that they do not generally provide information on a global scale, although with enough effort

\footnotetext{
${ }^{1}$ Also at Centre des Faibles Radioactivites, CNRS-CEA, Gif-surYvette, France.

${ }^{2}$ Presently at Lamont-Doherty Earth Observatory of Columbia University, Palisades, NY.
}

Copyright 1994 by the American Geophysical Union. they can potentially be made to do so. Ice core reconstructions of the concentrations of bioactive gases in air provide an integrated global signal which complements the proxy studies cited above. Variations in the concentrations of the most abundant bioactive gases $\left(\mathrm{CO}_{2}, \mathrm{CH}_{4}, \mathrm{~N}_{2} \mathrm{O}\right)$ reflect, in part, global scale changes in the marine and terrestrial biospheres. Atmospheric concentrations of $\mathrm{CH}_{4}$ have been found to vary with a period corresponding to that of the precession of the equinoxes [Chappellaz et al., 1990]. Concentrations are higher when temperatures are warmer and precipitation is greater. Glacial-interglacial variations in the concentration of $\mathrm{CO}_{2}$ have been attributed to changes in the fertility and carbon export of the upper water ecosystem [e. g., Mix, 1989a; Knox and McElroy, 1984], although variations in ocean circulation and other factors must also have played an important role (e. g., Boyle, 1988; Broecker, 1989). On a shorter timescale, the transient minimum in the $\mathrm{CO}_{2}$ concentration of air at the end of the last glacial termination reflects rapid growth of the land biosphere [Neftel et al., 1988].

The $\delta^{18} \mathrm{O}$ of $\mathrm{O}_{2}$ is an additional variable which reflects the global responses of the land and marine biospheres to climate change, albeit in a complex manner. The Dole effect is defined as the difference between the $\delta^{18} \mathrm{O}$ of atmospheric $\mathrm{O}_{2}$ in air and the $\delta^{18} \mathrm{O}$ of contemporaneous seawater. The magnitude of the Dole effect, which today is about $+23.5 \%$ [Kroopnick and Craig, 1972], mainly reflects the isotopic composition of $\mathrm{O}_{2}$ produced by marine and terrestrial photosynthesis, as well as the extent to which the heavy isotope is discriminated against during respiration. As previously discussed, $\delta^{18} \mathrm{O}$ of 
atmospheric $\mathrm{O}_{2}$ varied over glacial/interglacial timescales in response to changes in the $\delta^{18} \mathrm{O}$ of seawater [Horibe et al., 1985; Bender et al., 1985, Sowers et al., 1993]. Other factors, which are of secondary importance in controlling the $\delta^{18} \mathrm{O}$ of atmospheric $\mathrm{O}_{2}$, are (1) changes in terrestrial and marine fertility, (2) varying isotope fractionation associated with the hydrologic cycle, and (3) changes in respiratory isotope effects on either a species or community level.

The response time of $\delta^{18} \mathrm{O}$ of $\mathrm{O}_{2}$ is comparable to the turnover time of $\mathrm{O}_{2}$ in air with respect to photosynthesis and respiration, about $1.2 \mathrm{kyr}$ (Table 1). In general, increases in the ratio of terrestrial to marine production will cause the $\delta^{18} \mathrm{O}$ of atmospheric $\mathrm{O}_{2}$ to rise. Within the terrestrial realm, largescale changes in ecology, precipitation, and humidity can all cause variability in the Dole effect.

In this paper we present a record of variations in the Dole effect over the last $130 \mathrm{kyr}$, based on the analysis of air occluded in the GISP2 and Vostok ice cores. We then explore the implications of this record for changes in the fertility of the land and marine biospheres and changes in hydrologic fractionation of oxygen isotopes during the Late Pleistocene.

\section{Dole Effect Reconsidered}

The $\delta^{18} \mathrm{O}$ of surface seawater today is, on average, close to zero on the SMOW scale, while that of $\mathrm{O}_{2}$ is constant throughout the atmosphere at a value of about $+23.5 \%$. Over the time period of interest here, photosynthesis and respiration are the most important reactions producing and consuming $\mathrm{O}_{2}$. The isotopic composition of $\mathrm{O}_{2}$ in air must therefore be understood in terms of isotope fractionation associated with these reactions [Lane and Dole, 1956; Berry, 1992; and references therein].
The $\delta^{18} \mathrm{O}$ of $\mathrm{O}_{2}$ produced by photosynthesis is similar to that of the source water [e. g., Guy et al., 1993]. The $\delta^{18} \mathrm{O}$ of $\mathrm{O}_{2}$ produced by marine plants today is thus $0 \%$. The $\delta^{18} \mathrm{O}$ of $\mathrm{O}_{2}$ produced on the continents has been estimated to lie between +4 and $+8 \%$ [Dongmann, 1974; Farquhar et al., 1993]. These elevated $\delta^{18} \mathrm{O}$ values are the result of elevated leaf water $\delta^{18} \mathrm{O}$ values resulting from evapotranspiration.

The $\delta^{18} \mathrm{O}$ of $\mathrm{O}_{2}$ consumed by respiration is $\sim 20 \%$ less than that of the source $\mathrm{O}_{2}$ [Guy et al., 1993; Kiddon et al., 1993]. At isotopic steady state, the $\delta^{18} \mathrm{O}$ of $\mathrm{O}_{2}$ molecules actually consumed by respiration must be the same as the $\delta^{18} \mathrm{O}$ of $\mathrm{O}_{2}$ produced by photosynthesis [Lane and Dole, 1956]. Today this constraint is satisfied with $\delta^{18} \mathrm{O}$ of atmospheric $\mathrm{O}_{2}=+$ $23.5 \%$. In the event of deviations, the steady state value of the Dole effect would be restored with an e-folding time equal to the turnover time of $\mathrm{O}_{2}$ in air, $\sim 1.2 \mathrm{kyr}$.

We now recognize that several additional processes affect the $\delta^{18} \mathrm{O}$ of atmospheric $\mathrm{O}_{2}$ [e. g., Berry, 1992]. The most important is evapotranspiration, which can cause very large enrichments in the $\delta^{18} \mathrm{O}$ of leaf water of land plants because of the preferrential evaporation of the light isotope [Dongmann et al., 1974; Farris and Strain, 1978; Forstel, 1978]. Due largely to the meticulous work of R. D. Guy and colleagues [Guy et al., 1989, 1992], our estimates of isotope fractionation during photosynthesis and respiration are based on much better data than was available to Lane and Dole [1956]. In addition, we now have better estimates of the relative rates of land and ocean production. Finally, we can now begin to assess the impact of several additional processes on the Dole effect, including isotopic exchange between $\mathrm{CO}_{2}$ and $\mathrm{O}_{2}$ driven by photochemical processes in the stratosphere (first suggested by Dole et al. [1954], p. 66), mixing in the aphotic zone of the ocean and its influence on the $\delta^{18} \mathrm{O}$ of $\mathrm{O}_{2}$ consumed by respiration in that environment, and equilibrium

Table 1a. Terrestrial Mass Balance of $\mathrm{O}_{2}$ and $\delta^{18} \mathrm{O}$ of $\mathrm{O}_{2}$

\begin{tabular}{|c|c|c|c|}
\hline Production term & & Production & Reference \\
\hline $\begin{array}{l}\text { Gross production excluding photorespired } \mathrm{O}_{2} \text { (GPP) } \\
\text { Gross production including photorespiration }(14.1 / 0.69)\end{array}$ & & $\begin{array}{l}14.1 \\
20.4\end{array}$ & $\begin{array}{l}\text { Farquhar et al. }[1993] \\
\text { Farquhar et al. }[1980]\end{array}$ \\
\hline Process & $\begin{array}{c}\text { Fraction of respiratory } \\
\mathrm{O}_{2} \text { consumption }\end{array}$ & Isotope effect & Reference \\
\hline$\delta^{18} \mathrm{O}$ of terrestrial photosynthetic $\mathrm{O}_{2}$ w. r. t. SMOW & & $4.4 \%$ & Farquhar et al. [1993] \\
\hline \multicolumn{4}{|l|}{ Discrimination against $\mathrm{O}^{18}$ during respiration } \\
\hline $\begin{array}{l}\text { Dark respiration } \\
\text { Mehler reaction }\end{array}$ & $\begin{array}{l}59 \% \\
10 \%\end{array}$ & $\begin{array}{l}18.0 \\
15.1\end{array}$ & $\begin{array}{l}\text { Guy et al. }[1992,1993] \\
\text { Guy et al. }[1992]\end{array}$ \\
\hline $\begin{array}{l}\text { Photorespiration } \\
\text { Flux weighted terrestrial respiratory isotope effect, } \\
\text { excluding dark respiration }\end{array}$ & $31 \%$ & $\begin{array}{l}21.2 \% \\
18.7 \%\end{array}$ & Guy et al. [1992] \\
\hline Equilibrium enrichment in $\delta^{18} \mathrm{O}$ of leaf water w. r. t. air & & $+0.7 \%$ & Benson and Krause [1984] \\
\hline Terrestrial respiratory isotope effect $(=18.7 \% o-0.7 \% o)$ & & $18.0 \%$ & \\
\hline Terrestrial Dole effect & & $22.4 \%$ & \\
\hline
\end{tabular}


Table 1b. Marine Mass Balance of $\mathrm{O}_{2}$ and $\delta^{18} \mathrm{O}$ of $\mathrm{O}_{2}$

\begin{tabular}{llll}
\hline Production term & $\begin{array}{c}\text { Production } \\
\left(\times 10^{15} \text { moles/yr }\right)\end{array}$ & Reference \\
\hline Marine gross production (=4 x seasonal net production) & 12 & Keeling and Shertz [1992] \\
Marine gross production - recycling within the ocean & 10.6 & Reference \\
\hline Process & Isotope effect & \\
\hline
\end{tabular}

$\delta^{18} \mathrm{O}$ of $\mathrm{O}_{2}$ produced by marine photosynthesis

$\delta^{18} \mathrm{O}$ of marine photosynthetic $\mathrm{O}_{2} \quad 0 \%$

Discrimination against ${ }^{18} \mathrm{O}$ during marine respiration

Average marine $\varepsilon_{R}$ (applies to euphotic respiration)

Effective $\varepsilon_{R}$ for respiration below the euphotic zone

Equilibr. enrichment in $\delta^{18} \mathrm{O}$ of $\mathrm{O}_{2}$ in water w.r.t. air

Effective $\varepsilon_{\mathrm{R}}$ for marine respiration*

$20 \%$

$12 \%$

$0.7 \%$

$18.9 \%$

$18.9 \%$

$*=0.95 \times(20 \% 0-0.7 \% 0)+0.05 \times 12 \%$

isotope fractionation between $\mathrm{O}_{2}$ in air and $\mathrm{O}_{2}$ dissolved in seawater.

\section{$\delta^{18} \mathrm{O}$ of $\mathrm{O}_{2}$ Produced During Photosynthesis}

In the terrestrial environment, gross production is the production term of interest relative to the Dole effect because all photosynthetic $\mathrm{O}_{2}$ escapes from leaves to label the atmosphere before any is consumed intracellularly. This is the case because leaves are open to diffusion of $\mathrm{CO}_{2}$, a gas whose atmospheric concentration is only 0.0016 times that of $\mathrm{O}_{2}$.

In the ocean, photosynthesis takes place in the mixed layer or in adjacent underlying waters. Gas in the mixed layer equilibrates with the atmosphere over a timescale of weeks, while gas in the underlying seasonal thermocline equilibrates over a timescale of months. We assume that the average timescale for gas equilibration between the euphotic zone and the atmosphere is 30 days, the euphotic zone is $60 \mathrm{~m}$ thick and its $\left[\mathrm{O}_{2}\right]$ is $250 \mu \mathrm{mol} / \mathrm{L}$, the ratio of net/total production is 0.25 , and net primary production is $8.5 \mathrm{~mol} \mathrm{~m}^{-2} \mathrm{yr}^{-1}$ (Table 1). From these numbers we calculate that gross primary production is 34 moles $\mathrm{m}^{-2} \mathrm{yr}^{-1}$. We also calculate that $88 \%$ of photosynthetic $\mathrm{O}_{2}$ goes into the atmosphere, and $12 \%$ is consumed by respiration before it crosses the air/sea interface to label the atmospheric $\mathrm{O}_{2}$ pool. We therefore discount gross oceanic production by $12 \%$ in computing the $\delta^{18} \mathrm{O}$ balance of $\mathrm{O}_{2}$.

Guy et al. [1993] recently showed that $\delta^{18} \mathrm{O}$ of $\mathrm{O}_{2}$ produced by spinach thylakoids (photosynthetic membranes) was

Table 1c. Calculation of the global Dole effect, model leaf water enrichment, and atmospheric $\mathrm{O}_{2}$ turnover time

Isotope effect

\begin{tabular}{lr}
\hline Stratospheric diminution due to $\mathrm{O}$ isotope exchange of $\mathrm{O}_{2}$ and $\mathrm{CO}_{2}$ & $0.4 \% \circ$ \\
Calculated Dole effect* & $20.8 \% \circ$ \\
Observed Dole effect & $23.5 \% \circ$ \\
Leaf water enrichment giving observed Dole effect, all other terms constant & $8.5 \% \circ$
\end{tabular}

Turnover time

\begin{tabular}{ll}
\hline Turnover time of atmospheric $\mathrm{O}_{2}^{* *}$ & $1.2 \mathrm{kyr}$
\end{tabular}

*=[fraction of production on land $x$ land Dole effect $]+[$ fraction of production in oceans $x$ marine Dole effect] - stratospheric diminution

$* *=($ atmospheric inventory $/$ [terrestrial production + marine production] $)=\left(3.7 \times 10^{19}\right.$ moles $/[20.4+$ $10.6] \times 10^{15}$ moles/yr] 
indistinguishable from that of ambient water in which the thylakoids were suspended. Guy et al. and earlier workers [e. g., Stevens et al., 1975] found slight enrichments ( 1 \%o) in the $\delta^{18} \mathrm{O}$ of $\mathrm{O}_{2}$ produced by phytoplankton relative to ambient waters. They attributed these enrichments to algal respiration in the photosynthesizing cultures rather than to photosynthetic fractionation. Thus the $\delta^{18} \mathrm{O}$ of photosynthetic $\mathrm{O}_{2}$ has the same isotopic composition as its source water, or very nearly so.

Marine photosynthesis. The $\delta^{18} \mathrm{O}$ of surface seawater ranges from about $-1 \%$ to $+1 \%$ on the SMOW scale, averaging nearly zero [Craig and Gordon, 1965]. Thus the $\delta^{18} \mathrm{O}$ of $\mathrm{O}_{2}$ produced by marine photosynthesis is $\sim 0 \%$.

Land photosynthesis. To understand the factors that control the $\delta^{18} \mathrm{O}$ of terrestrially produced $\mathrm{O}_{2}$, one needs to understand the factors controlling the $\delta^{18} \mathrm{O}$ of leaf $\mathrm{H}_{2} \mathrm{O}$. Leaf water ultimately originates from surface seawater, but its isotopic composition, relative to the source, is fractionated by equilibrium and kinetic effects attending evaporation and precipitation [Craig and Gordon, 1965]. The $\delta^{18} \mathrm{O}$ of precipitation varies spatially and temporally and averages about - $7 \%$. This water is absorbed into the roots, stems, and branches of plants without significant fractionation. Water in leaves, however, is enriched in ${ }^{18} \mathrm{O}$ because, during evapotranspiration, the light isotope evaporates more rapidly. Quantitative descriptions of the leaf water enrichment assume a two-step process for evaporation. First, leaf water evaporates into saturated air within the "head space" (stomata) of the leaf with a composition fixed by equilibrium between leaf water and the head space vapor. Second, leaf water escapes from the stomata into free air which has a humidity $<100 \%$.

For a simple model in which evapotranspiration is simulated by the steady state evaporation of water from a sheet of paper, the "leaf water" enrichment is given by the "Craig equation:"

$$
\delta_{\text {leaf }}-\delta_{\text {stem }}=\varepsilon^{*}+(1-h) \varepsilon_{\mathrm{k}}+h\left(\delta_{\text {atm }}-\delta_{\text {stem }}\right)
$$

[Craig and Gordon, 1965; Dongmann, 1974; Farris and Strain, 1978], where $\delta$ is the $\delta^{18} \mathrm{O}$ of water. The subscripts leaf, stem, and atm refer to leaf water, stem water (i. e., local meteoric source water), and atmospheric water, respectively. $h$ is relative humidity, $\varepsilon^{*}$ is the equilibrium isotope effect for evaporation of water (liquid) to water (gas), and $\varepsilon_{k}$ is the kinetic isotope effect associated with the diffusion of water out of the stomata into the free atmosphere. $\varepsilon^{*}$ is about $+9 \%$ and $\varepsilon_{\mathrm{k}}$ is about $27 \%$ [Farquhar et al., 1993; Yakir, D., J. Berry, L. Giles, and C. B. Osmond, Isotopic heterogeneity of water in transpiring leaves: Identification of the component that controls the $\delta^{18} \mathrm{O}$ of atmospheric $\mathrm{O}_{2}$ and $\mathrm{CO}_{2}$, submitted to Plant and Cell Environment, 1994].

In the case where the relative humidity is $100 \%$ and atmospheric water is in equilibrium with soil water, the leaf water enrichment would be $0 \%$ relative to local meteoric water. In the case where the humidity is zero, the calculated leaf water enrichment is $\sim 36 \%$ relative to local meteoric water. Other factors affecting the $\delta^{18} \mathrm{O}$ of chloroplast water, and hence the $\delta^{18} \mathrm{O}$ of photosynthetic $\mathrm{O}_{2}$, include the normal diurnal variation in humidity (which is at a minimum in the afternoon), elevation of temperatures inside leaves relative to the surrounding air, non steady state conditions with respect to the leaf water balance (especially at night, when stomata close), variations in the kinetic isotope effect for the escape of leaf water due to the biological variability in the nature of the stomata [Farris and Strain, 1978], and variations in the $\delta^{18} \mathrm{O}$ of $\mathrm{H}_{2} \mathrm{O}$ gas in ambient air. Data in Figure 1, on the isotopic composition of leaf water from a forest in Julich, Germany, illustrate the expected diurnal cycle in the $\delta^{18} \mathrm{O}$ of leaf water, together with variations demonstrating the existence of complex disequilibrium effects.

At any time when the humidity is $<100 \%$, the ideal value for the isotopic composition of leaf water can be modified by advection of water through the leaf to the site of evaporation

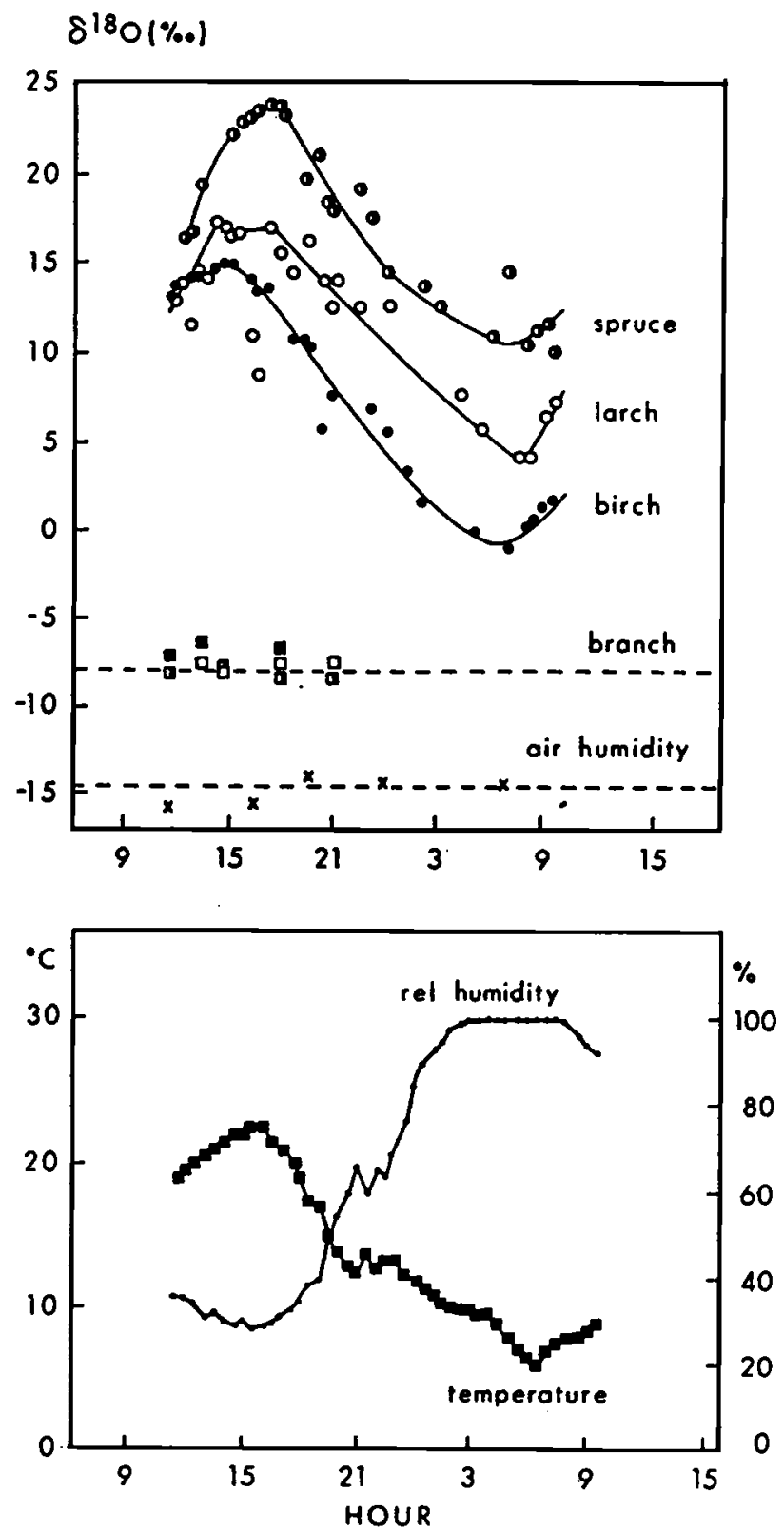

Figure 1. $\delta^{18} \mathrm{O}$ of $\mathrm{H}_{2} \mathrm{O}$ in leaf water of three trees, branch water, and air humidity as a function of time of day for a forest in Julich, Germany. Relative humidity and temperature are also shown. Redrawn from Forstel [1978]. 
and by back diffusion of leaf water from these sites. The isotopic composition of leaf water is thus intermediate between the $\delta^{18} \mathrm{O}$ value predicted by the Craig equation and the $\delta^{18} \mathrm{O}$ of stem water [Yakir et al., 1989; Yakir, D., J. Berry, L. Giles, and C. B. Osmond, Isotopic heterogeneity of water in transpiring leaves: Identification of the component that controls the $\delta^{18} \mathrm{O}$ of atmospheric $\mathrm{O}_{2}$ and $\mathrm{CO}_{2}$, submitted to Plant and Cell Environment, (1994).; Farquhar et al., 1993]. Of interest here is the ${ }^{18} \mathrm{O}$ enrichment in water in chloroplasts, where photosynthetic production of $\mathrm{O}_{2}$ occurs. Farquhar et al. [1993] pointed out that this value might be governed by the Craig equation (equation (1)), since chloroplasts are near the sites of evaporation on the surface of leaves, and presented strong supporting evidence. Yakir et al. (Yakir, D., J. Berry, L. Giles, and C. B. Osmond, Isotopic heterogeneity of water in transpiring leaves: Identification of the component that controls the $\delta^{18} \mathrm{O}$ of atmospheric $\mathrm{O}_{2}$ and $\mathrm{CO}_{2}$, submitted to Plant and Cell Environment, 1994) presented data showing that the $\delta^{18} \mathrm{O}$ of chloroplast water (and hence of photosynthetic $\mathrm{O}_{2}$ ) was intermediate between that predicted by the Craig equation and that of stem water. Thus the basic control on the ${ }^{18} \mathrm{O}$ enrichment of water in chloroplasts is under debate.

With respect to the Dole effect, the value of interest is the globally averaged $\delta^{18} \mathrm{O}$ of photosynthetic $\mathrm{O}_{2}$. This is equal to the time-averaged $\delta^{18} \mathrm{O}$ of chloroplast water during the photoperiod, weighted for the rate of photosynthetic $\mathrm{O}_{2}$ production. $\delta^{18} \mathrm{O}$ of leaf water, and hence photosynthetic $\mathrm{O}_{2}$, varies over all scales of space and time, making the globally averaged value extremely difficult to estimate. Recently, Farquhar et al. [1993] attempted such a calculation in another context and estimated a value of $+4.4 \%$ for the productivityweighted average $\delta^{18} \mathrm{O}$ of leaf water and hence photosynthetic $\mathrm{O}_{2}$ produced on land. We adopt this value in the calculations that follow but note that the $+4.4 \%$ value falls close to the lower end of the range of possible values suggested by Dongmann [1974].

\section{$\delta^{18} \mathrm{O}$ of $\mathrm{O}_{2}$ Consumed by Respiration}

Terrestrial respiration. Following Farquhar et al. [1980], we assume that the ratio $f$ of photorespiration to carboxylation (or total carbon fixation) is given by equation (4) in their paper (p. 79):

$$
\phi=\left(\mathrm{V}_{\mathrm{O} \max } / \mathrm{V}_{\mathrm{C} \max }\right) \times(\mathrm{O} / \mathrm{C}) \times\left(\mathrm{K}_{\mathrm{C}} / \mathrm{K}_{\mathrm{O}}\right) \times 10^{-3}
$$

where $\left(\mathrm{V}_{\mathrm{O} \text { max }} / \mathrm{V}_{\mathrm{C} \text { max }}\right)$ is the ratio of the maximum oxygenation velocity to the maximum carboxylation velocity of $\mathrm{RuP}_{2}$ carboxylase-oxygenase, and $\mathrm{O}$ is the $\mathrm{O}_{2}$ partial pressure $(210,000 \mathrm{ppmV}) . \mathrm{C}$ is the $\mathrm{CO}_{2}$ partial pressure in plant cells in ppmV, assumed to be equal to $0.7 \mathrm{x}$ partial pressure of $\mathrm{CO}_{2}$ in air. $\left(\mathrm{K}_{\mathrm{C}} / \mathrm{K}_{\mathrm{O}}\right)$ is the ratio of Michaelis Menton constants for carboxylation and oxygenation, respectively (460/330). For the preindustrial value of 280 parts per million by volume (ppmv) $\mathrm{CO}_{2}$ in air, $\phi=0.31$. Following Guy et al. [1992], we assume that the Mehler reaction accounts for $10 \%$ of terrestrial respiration. We assume that all dark respiration is via the cyanide-sensitive pathway. The partitioning of respiration is summarized in Table 1 .
Respiratory oxygen isotope fractionation $\left(\varepsilon_{R}\right)$ has recently been measured for the major biochemical pathways by Guy et al. $[1989,1992,1993]$. They determined $\varepsilon_{\mathrm{R}}$ to be about $18 \%$ for dark respiration by the cyanide-sensitive pathway and 25 $\% o$ for respiration by the alternative (cyanide-resistant) pathway. Guy et al. [1992] measured $\varepsilon_{\mathrm{R}}$ to be about $21.2 \%$ for photorespiration, and $15.3 \%$ for the Mehler reaction (in vivo photo-oxidation). We then calculate a value of $\varepsilon_{R}=18.8 \%$ for terrestrial respiration (Table 1). The true value is likely to be slightly higher because of the influence of cyanide resistant dark respiration.

Finally, we note that respiration consumes $\mathrm{O}_{2}$ from the liquid pool of cells. The $\delta^{18} \mathrm{O}$ in solution is enriched by $0.7 \%$ with respect to air [Benson and Krause, 1984], decreasing land fractionation with respect to the atmosphere by this amount.

Marine respiration. Kiddon et al. [1993] determined $\varepsilon_{\mathrm{R}}$ values for a range of microorganisms representative of common marine autotrophs and heterotrophs in culture. They measured $\varepsilon_{\mathrm{R}}$ values ranging from $15 \%$ to $25 \%$ and averaging close to $+20 \%$. Larger marine animals (as well as land plants and animals) have lower $\varepsilon_{R}$ values due to diffusion limitation of fractionation. In these organisms, $\varepsilon_{R}$ depends on rates at which light and heavy isotopes can diffuse to the site of respiration as well as on the biochemical fractionation [Lane and Dole, 1956; Epstein and Zeiri, 1988; Kiddon et al., 1993]. However, these animals are not important in the global $\mathrm{O}_{2}$ balance. The average value of $\varepsilon_{\mathrm{R}}$ for microorganisms studied by Kiddon et al. is close to that observed by Guy et al. [1992] and expected for cyanide-sensitive dark respiration based on work of Guy et al. [1989]. Nevertheless, for individual species there are differences which cannot be readily explained.

In this paper, we adopt a value of $20 \%$ for the marine value of $\varepsilon_{R}$. This value directly characterizes marine respiration in the euphotic zone of the ocean in and the upper part of the aphotic zone which equilibrates rapidly (i. e., seasonally) with the atmosphere. We neglect the fact that the marine respiratory isotope effect in nature must be higher in the light than in the dark (in which condition Kiddon et al. [1993] made all their measurements), since the isotope effect of $21.2 \%$ expected for photorespiration is higher than the isotope effect adopted here. Photorespiration is thought to be a minor pathway in the ocean. We note that respiration by the alternative pathway is associated with much more extensive isotopic fractionation than via the cyanide resistant pathway, but we have no way of assessing the relative rates for the two pathways. Finally, we note that the $\delta^{18} \mathrm{O}$ of the dissolved $\mathrm{O}_{2}$ pool of seawater is enriched with respect to the $\delta^{18} \mathrm{O}$ of air by $0.7 \%$ [Kroopnick and Craig, 1972]. This enrichment reflects the fact that ${ }^{18} \mathrm{O}^{16} \mathrm{O}$ is $0.7 \%$ more soluble in seawater than ${ }^{16} \mathrm{O}_{2}$ [Benson and Krause, 1984]. This enrichment decreases the ${ }^{18} \mathrm{O}$ fractionation relative to the atmosphere by 0.7 to $19.3 \%$.

A small fraction of marine respiration occurs within more isolated parts of the ocean (i. e., the main thermocline and the deep sea). In these areas, the $\mathrm{O}_{2}$ concentration is significantly depleted. The residual dissolved $\mathrm{O}_{2}$ is enriched in ${ }^{18} \mathrm{O}$ because $\mathrm{O}_{2}$ used for respiration was depleted in the heavy isotope [e. g., Kroopnick and Craig, 1976; Kroopnick, 1987]. We assume that $5 \%$ of gross production is remineralized in waters underlying the seasonal thermocline with an $\mathrm{O}_{2}$ concentration equal to $40 \%$ of saturation and a $\delta^{18} \mathrm{O}$ of $\mathrm{O}_{2}$ enriched by $8 \%$ with respect to surface seawater. (The percent saturation 
number is a rough estimate based on hydrographic sections of dissolved $\mathrm{O}_{2}$ concentration. The $\delta^{18} \mathrm{O}$ is estimated from the relationship between the $\delta^{18} \mathrm{O}$ of dissolved $\mathrm{O}_{2}$ in subsurface waters and the $\mathrm{O}_{2}$ undersaturation [Bender, 1990].) The $\delta^{18} \mathrm{O}$ of $\mathrm{O}_{2}$ utilized by respiration in these waters will be equal to $\delta^{18} \mathrm{O}$ (dissolved $\mathrm{O}_{2}$ ) $-\varepsilon_{\mathrm{R}}$, or 8-20\%o $=12 \%$. The effective respiratory isotope effect for seawater with respect to the $\delta^{18} \mathrm{O}$ of ambient dissolved $\mathrm{O}_{2}$ is then: $0.95 \times 19.3 \% \circ+0.05 \times 12 \%$ $=18.9 \%$.

\section{Effect of Isotopic Exchange Between $\mathrm{O}_{2}$ and $\mathrm{CO}_{2}$ in the Stratosphere on the $\delta^{18} \mathrm{O}$ of $\mathrm{O}_{2}$}

Recently, Gamo et al. [1989], Yung et al. [1991], Thiemens et al. [1991], and Wen and Thiemens [1993] demonstrated that isotopic exchange between $\mathrm{O}_{2}$ and $\mathrm{CO}_{2}$ occurs in the stratosphere and discussed its mechanism. $O\left({ }^{1} \mathrm{D}\right)$, which ultimately derives from $\mathrm{O}_{2}$, reacts with $\mathrm{CO}_{2}$ to form the $\mathrm{CO}_{3}$ transition state complex. The symmetry properties of this complex are different for $\mathrm{C}^{16} \mathrm{O}_{3}, \mathrm{C}^{16} \mathrm{O}_{2}{ }^{17} \mathrm{O}$, and $\mathrm{C}^{16} \mathrm{O}_{2}{ }^{18} \mathrm{O}$. The difference in symmetry properties causes ${ }^{17} \mathrm{O}$ and ${ }^{18} \mathrm{O}$ to be enriched in the $\mathrm{CO}_{2}$ that is produced by the decay of $\mathrm{CO}_{3}$. These heavy isotope enrichments are anomalous in the sense that they are the same for ${ }^{17} \mathrm{O}$ as for ${ }^{18} \mathrm{O}$ [Wen and Thiemens, 1993]. In almost all materials, the ${ }^{17} \mathrm{O}$ enrichments are roughly half those of ${ }^{18} \mathrm{O}$, corresponding to the number of mass units by which ${ }^{18} \mathrm{O}$ and ${ }^{17} \mathrm{O}$ are heavier than the major isotope $\left({ }^{16} \mathrm{O}\right)$.

The magnitude of the stratospheric $\mathrm{CO}_{2}$ enrichment, with respect to its tropospheric value, increases with height to about $11 \%$ between 27 and $35 \mathrm{~km}$. The ${ }^{17} \mathrm{O}$ enrichment in stratospheric $\mathrm{CO}_{2}$ is anomalous as it is nearly the same as the ${ }^{18} \mathrm{O}$ enrichment rather than half [Thiemens et al., 1991], as noted above. Since $\mathrm{O}_{2}$ is the ultimate source $O\left({ }^{\prime} \mathrm{D}\right)$ reacting with $\mathrm{CO}_{2}$, the overall reaction represents isotopic exchange between $\mathrm{CO}_{2}$ and $\mathrm{O}_{2}$ in the stratosphere:

$$
\mathrm{C}^{16} \mathrm{O}_{2}+{ }^{18} \mathrm{O}^{16} \mathrm{O} \longrightarrow \mathrm{C}^{18} \mathrm{O}^{16} \mathrm{O}+{ }^{16} \mathrm{O}_{2} \text {. }
$$

The effect of this transfer of ${ }^{18} \mathrm{O}$ from $\mathrm{O}_{2}$ to $\mathrm{CO}_{2}$ is to decrease the $\delta^{18} \mathrm{O}$ of atmospheric $\mathrm{O}_{2}$. The question arises as to whether oxygen compounds other than $\mathrm{O}_{2}$ can be the ultimate source of $\mathrm{O}$ exchanging with $\mathrm{CO}_{2}$. The answer is no, because the concentration of other O-bearing compounds (e. g., $\mathrm{OH}, \mathrm{H}_{2} \mathrm{O}$ ) in the stratosphere is extremely low.

The quantitative effect of this exchange on the $\delta^{18} \mathrm{O}$ of atmospheric $\mathrm{O}_{2}$ can be estimated by scaling the stratospheric ${ }^{18} \mathrm{O}$ enrichment of $\mathrm{CO}_{2}$ relative to the tropospheric value (taken as $11 \% o$ ); [Thiemens et al., 1991]) by the ratio of the $\mathrm{CO}_{2}$ concentration of air to the $\mathrm{O}_{2}$ concentration (353 ppmv / $210,000 \mathrm{ppmv}$ ), by the ratio of the turnover time of $\mathrm{O}_{2}$ in air to the residence time of the troposphere with respect to exchange with the stratosphere (1.2 kyr / 56 years), and by a factor of -1 (since the effect on the $\delta^{18} \mathrm{O}$ of $\mathrm{O}_{2}$ is inverse to that for $\mathrm{CO}_{2}$ ). (The residence time of $\mathrm{O}_{2}$ in air is derived in Table 1 , and the time assumed to be required for exchange of the stratosphere into the troposphere, 56 years, is from Schmidt and Khedim [1991].) One then computes that photochemical isotope exchange between $\mathrm{CO}_{2}$ and $\mathrm{O}_{2}$ in the stratosphere lowers the $\delta^{18} \mathrm{O}$ of atmospheric $\mathrm{O}_{2}$ by $0.4 \%$. There is obviously considerable uncertainty in this number.
M. Thiemens (personal communication, 1993) has pointed out that this estimated stratospheric $\delta^{18} \mathrm{O}$ decrease of $0.4 \% o$ should be accompanied by a $\delta^{17} \mathrm{O}$ decrease of the same amount. These changes would lead to a non-mass-dependent fractionation of ${ }^{17} \mathrm{O}$ (defined as $\delta^{17} \mathrm{O}-0.5 \delta^{18} \mathrm{O}$ ) of $0.2 \%$, well within the limits of detection. Data on the current value and its change through time would allow one to determine relative rates at which the non-mass-dependent anomaly is produced by photochemical reactions in the stratosphere and destroyed by photosynthesis and respiration.

\section{Summary of the Discussion of the Dole Effect}

On the basis of the preceding presentation (summarized in Table 1), we define three terms relevant to the discussion of the observed Dole effect and its change through time. The "terrestrial Dole effect" is defined as the hypothetical Dole effect when $\mathrm{O}_{2}$ and $\mathrm{CO}_{2}$ exchange isotopically only as the result of photosynthesis and respiration on land. The "marine Dole effect" is defined analogously. The "stratospheric diminution of the Dole effect" is the decrease in the $\delta^{18} \mathrm{O}$ of $\mathrm{O}_{2}$ in air due to isotope exchange between $\mathrm{O}_{2}$ and $\mathrm{CO}_{2}$ in the stratosphere. The various terms are summarized in Table 1. The estimate for marine production is calculated from seasonal net $\mathrm{O}_{2}$ production as estimated by Keeling and Shertz [1992], assuming that gross $\mathrm{O}_{2}$ production is four times seasonal net $\mathrm{O}_{2}$ production. Other terms are taken from the literature or estimated as described above.

The calculated value for the Dole effect is then the productivity-weighted values of the terrestrial and marine Dole effects minus the stratospheric diminution: $+20.8 \%$. This value is considerably less than observed $(+23.5 \%$ o). The difference between the expected value and the observed value reflects errors in our estimates and, conceivably, unrecognized processes. Recognizing the contribution of cyanide-resistant dark respiration would also increase the calculated value of the Dole effect.

We believe that the biggest current uncertainty lies in the $\delta^{18} \mathrm{O}$ of leaf water. One can explain the observed value of the Dole effect by assuming a value of $+8.7 \%$, rather than +4.4 $\%$, for the $\delta^{18} \mathrm{O}$ of leaf water, keeping everything else constant. Observations of the $\delta^{18} \mathrm{O}$ of water in natural leaves from temperate and tropical forests during the growing season [Dongmann et al., 1974; Forstel, 1978; Zundel et al., 1978] are compatible with the higher value, but we should not attach too much importance to this observation because of natural variability in the $\delta^{18} \mathrm{O}$ of leaf water. Nonetheless, we emphasize uncertainty in the $\delta^{18} \mathrm{O}$ of leaf water for three reasons. First, the leaf water enrichment is the second most important cause (after respiratory isotope discrimination) of the stationary ${ }^{18} \mathrm{O}$ enrichment of $\mathrm{O}_{2}$ relative to seawater. Second, the term is highly variable on all space and time scales and therefore very difficult to quantify. Third, and most important, there is no way to explain the Dole effect without invoking a terrestrial term (i. e., leaf water enrichment $+\varepsilon_{R}$ ) greater than the observed atmospheric $\mathrm{O}_{2} \delta^{18} \mathrm{O}$ enrichment of + $23.5 \%$.

In the ensuing discussion, we regard the leaf water $\delta^{18} \mathrm{O}$ estimate of Farquhar et al. [1993], $4.4 \%$, as a lower limit, since we doubt that uncertainties in other terms can account for the discrepancy from the calculated Dole effect of $20.8 \%$ and 
the observed value. We regard the leaf water value of $+8.7 \%$, which brings the calculation into agreement with observation, as an upper limit, since part of the discrepancy between calculation and observation may be due to uncertainties indicated above (such as overestimation of marine production and neglect of the large ${ }^{18} \mathrm{O}$ fractionation associated with alternative pathway respiration).

\section{Changes in the $\delta^{18} \mathrm{O}$ of atmospheric $\mathrm{O}_{2}$ and the Dole Effect During the Last $130 \mathrm{kyr}$}

Records of the $\delta^{18} \mathrm{O}$ of $\mathrm{O}_{2}$ trapped in bubbles versus depth in the Vostok and GISP2 ice cores [Sowers et al., 1991; Sowers et $a l ., 1993$ ] allow us to reconstruct variations in the $\delta^{18} \mathrm{O}$ of atmospheric $\mathrm{O}_{2}$ and the Dole effect. For these reconstructions we need the following information: (1) data on the $\delta^{18} \mathrm{O}$ of $\mathrm{O}_{2}$ as a function of depth in the ice cores, (2) data on the $\delta^{15} \mathrm{~N}$ of $\mathrm{N}_{2}$ for each ice core sample to correct the $\delta^{18} \mathrm{O}$ of $\mathrm{O}_{2}$ for gravitational fractionation [e. g., Craig et al., 1988]; (3) estimates of the age of the gas in each ice core sample we studied, and (4) a record of the $\delta^{18} \mathrm{O}$ of seawater $\left(\delta^{18} \mathrm{O}_{\text {sw }}\right)$ versus age during the relevant time period. We can then compute the Dole effect as a function of time by subtracting $\delta^{18} \mathrm{O}_{\mathrm{sw}}$ from $\delta^{18} \mathrm{O}$ of contemporaneous atmospheric $\mathrm{O}_{2}\left(\delta^{18} \mathrm{O}_{\text {atm }}\right)$. We must calculate the Dole effect using compatible chronologies of deep sea sediments and ice cores. Relative errors in the chronostratigraphies introduce artifacts in the Dole effect curves since one would be subtracting $\delta^{18} \mathrm{O}_{\mathrm{atm}}$ at one time from $\delta^{18} \mathrm{O}_{\text {sw }}$ at another. Chronological errors introduce errors into the calculated magnitude of changes in the Dole effect as well as into the timing of the changes. The problem is obviously most acute at those times when $\delta^{18} \mathrm{O}_{\mathrm{sw}}$ and $\delta^{18} \mathrm{O}_{\text {atm }}$ change rapidly.

For the seawater curve we use $\delta^{18} \mathbf{O}$ data on the benthic foram Uvigerina senticosa from deep sea sediment core V 19-30 [Shackleton and Pisias, 1985]. The chronology is the SPECMAP chronology. We correct for the influence of bottom water temperature changes over the last $130 \mathrm{kyr}$ on the foram $\delta^{18} \mathrm{O}$ record as described by Sowers et al. [1993].

The chronology for the GISP2 ice core is based on annual layer counting throughout the interval relevant to this study [Alley et al., 1993]. Ice age-gas age differences ( $\Delta$ age values) are calculated as described by Sowers et al. [1993b]. $\Delta$ age is $220 \pm 50$ years for Holocene samples of GISP2 increasing to $630 \pm 100$ years for glacial samples. For the GISP2 samples, $\Delta$ age adds only a very small uncertainty to the calculated value of the Dole effect.

The chronology we adopt for Vostok is that of Sowers et al. [1993]. They derived a timescale for the Vostok core by correlating their $\delta^{18} \mathrm{O}_{\text {atm }}$ record with the $\delta^{18} \mathrm{O}_{\mathrm{sw}}$ curve (from the V 19-30 core) which had been placed into the SPECMAP timescale. This chronology appears to be robust between 0 $20 \mathrm{kyr}$ and 60-130 kyr. It is weak for the intervening period because the absence of large variations in $\delta^{18} \mathrm{O}_{\text {atm }}$ and $\delta^{18} \mathrm{O}_{\mathrm{sw}}$ make correlation difficult. This chronology has several other weaknesses with respect to the objective of this paper. First, it is derived using the method of Martinson et al. [1982] with eight coefficients for the $133 \mathrm{kyr}$ record. This limited number of coefficients leads to a "stiff" fit which does not reproduce the timing of high-frequency events very well. Second, we account for the lag in the response of $\delta^{18} \mathrm{O}_{\mathrm{atm}}$ to $\delta^{18} \mathrm{O}_{\mathrm{sw}}$ in a

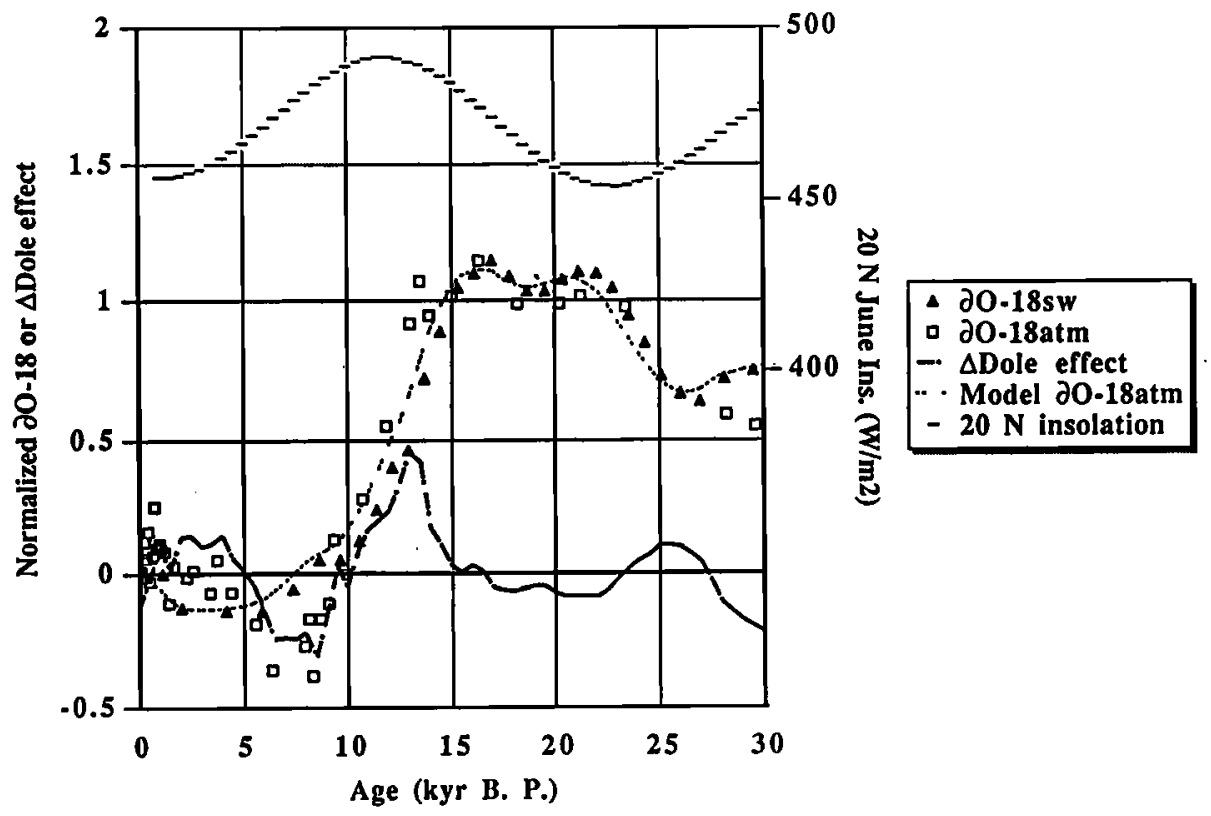

Figure 2. Experimental values of $\delta^{18} \mathrm{O}_{s w}$ and $\delta^{18} \mathrm{O}_{\text {atm }}$ from the GISP2 ice core versus age. The $\delta^{18} \mathrm{O}_{\mathrm{sw}}-$ age curve is from T. Sowers et al. (manuscript in preparation, 1994). The $\delta^{18} \mathrm{O}_{\text {atm }}$ - age curve is from Sowers et al. [1993]. Also plotted are values of $\Delta$ Dole effect (heavy line), calculated from data interpolated to $0.5-\mathrm{kyr}$ intervals, and values $\delta^{18} \mathrm{O}_{\text {atm }}$ predicted by a simple model assuming constant biogeochemical forcing (i. e., global carbon fluxes, leaf water fractionation, and photosynthetic and respiratory oxygen isotope fractionation as observed today). 
way which, ideally, forces the Dole effect to be about $+0.2 \%$ relative to the present value during glacial terminations. Our calculated value of the Dole effect is larger during the terminations, possibly because $\delta^{18} \mathrm{O}_{\text {atm }}$ appears to decrease more rapidly than $\delta^{18} \mathrm{O}_{\text {sw }}$ during these events. Third, Sowers et al.'s approach to deriving a chronology for the Vostok core (by correlating $\delta^{18} \mathrm{O}$ records) minimizes variations in the Dole effect throughout the record. Largely because of these problems, our curve of changes in the Dole effect as a function of time is provisional and will evolve as we get new data and improve the chronology of ice and sediment cores.

Values of $\delta^{18} \mathrm{O}_{\text {atm }}$ for Vostok presented here are based on values of $\delta^{18} \mathrm{O}$ of $\mathrm{O}_{2}$ and $\delta^{15} \mathrm{~N}$ of $\mathrm{N}_{2}$ reported by Sowers et al. [1993]. These results were from trapped gas samples from the $3 \mathrm{G}$ core which were extracted at the Laboratoire de Glaciologie et Geophysique de l'Environnement, in Grenoble, France, sealed in glass ampoules, and analyzed at the University of Rhode Island (URI). More recent results suggest an analytical problem with these results (which we call the "Grenoble Vostok $3 \mathrm{G}$ samples" in the ensuing discussion). First, $\delta^{18} \mathrm{O}_{\text {atm }}$ values measured at URI for GISP2 samples (Figure 2) are systematically lower, by $\sim 0.2 \%$, than values measured for Grenoble $3 \mathrm{G}$ samples. Second, $\delta^{18} \mathrm{O}_{\mathrm{atm}}$ values of samples from the Vostok $5 \mathrm{G}$ core, back to $30 \mathrm{kyr}$ in age, extracted and measured at URI [Malaize, 1993], agree with values from the GISP2 core as opposed to Grenoble Vostok 3G data. An exhaustive review of our standard and methods calibrations revealed no errors except that the $\delta^{15} \mathrm{~N}$ of our standard may have shifted by $0.04 \%$ during the period the Grenoble Vostok $3 \mathrm{G}$ samples were analyzed. Such a shift would cause $\delta^{18} \mathrm{O}_{\text {atm }}(=$ $\delta^{18} \mathrm{O}-2 \times \delta^{15} \mathrm{~N}$ ) to be $0.04 \%$ light for some samples and heavy by the same amount for others.

To address the question of calibration empirically, we prepared and analyzed nine samples from the $3 \mathrm{G}$ core at URI ("URI Vostok $3 \mathrm{G}$ samples"). In Figure $3, \delta^{15} \mathrm{~N}$ and $\delta^{18} \mathrm{O}$ are plotted versus depth, down to $700 \mathrm{~m}$, for URI Vostok 3G samples, Grenoble Vostok $3 \mathrm{G}$ samples, and Vostok $5 \mathrm{G}$ samples (analyzed entirely at URI). $\quad \delta^{18} \mathrm{O}$ values for all three data sets are in excellent agreement throughout this interval. At depths above $650 \mathrm{~m}$, where we have the greatest density of comparable samples, $\delta^{15} \mathrm{~N}$ values for the Vostok $5 \mathrm{G}$ samples and URI Vostok 3G samples are systematically higher than Grenoble Vostok 3G samples by an average value of +0.10 $\%$. This offset most likely reflects an undetected artifact associated with sealing air samples in glass flasks, but we cannot confidently explain its origin.

In this paper we correct the $\delta^{15} \mathrm{~N}$ of all Grenoble Vostok $3 \mathrm{G}$ samples by $+0.10 \%$. This correction lowers $\delta^{18} \mathrm{O}_{\text {atm }}$ of these samples by $0.20 \%$ and brings them into excellent agreement with $\delta^{18} \mathrm{O}_{\text {atm }}$ values for GISP2.

\section{Timing and Magnitude of Variations in the Dole Effect During the Last 130 KYR}

\section{GISP2 Record}

In Figure 2 we plot $\delta^{18} \mathrm{O}_{\mathrm{sw}}, \delta^{18} \mathrm{O}_{\mathrm{atm}}$, and $\Delta$ Dole effect versus age for the past $30 \mathrm{kyr}$, based on data from the GISP2 ice core. $\delta^{18} \mathrm{O}_{\mathrm{sw}}$ and $\delta^{18} \mathrm{O}_{\mathrm{atm}}$ are plotted with modern values normalized to zero. We define $\Delta$ Dole effect as the difference between the Dole effect at time $t$ in the past and the Dole effect today:

$$
\Delta \text { Dole effect }(t)=\Delta \delta^{18} O_{\text {atm }}(t)-\Delta \delta^{18} O_{s w}(t)
$$

We also calculate and plot the hypothetical value of $\delta^{18} \mathrm{O}_{\mathrm{atm}}$ if the biogeochemical forcing had been constant, that is to say, if the Dole effect had varied only because of the lag in the atmospheric response to a change in $\delta^{18} \mathrm{O}_{\mathrm{sw}}$. Finally, we plot average June insolation at $20^{\circ} \mathrm{N}$. This term gives an index of summertime insolation changes in subtropical latitudes of the northern hemisphere. Relative variations of June insolation at $20^{\circ} \mathrm{N}$ are very close to those of summertime northern hemisphere insolation and inferred variations in low-latitude precipitation as deduced from modeling studies [Prell and Kutzbach, 1987]. We focus on low latitudes because many climate records from this region have a substantial amount of spectral density in the precessional frequencies (19 and 23 kyr) which correspond to the period of dominant variability in the Dole effect (see below).

Between about 16 and $21 \mathrm{kyr}$ B. P. and again for the last 3 $\mathrm{kyr}, \delta^{18} \mathrm{O}_{\mathrm{atm}}$ and $\delta^{18} \mathrm{O}_{\mathrm{sw}}$ are nearly constant. At these times of very different climate, the Dole effect is at steady state and
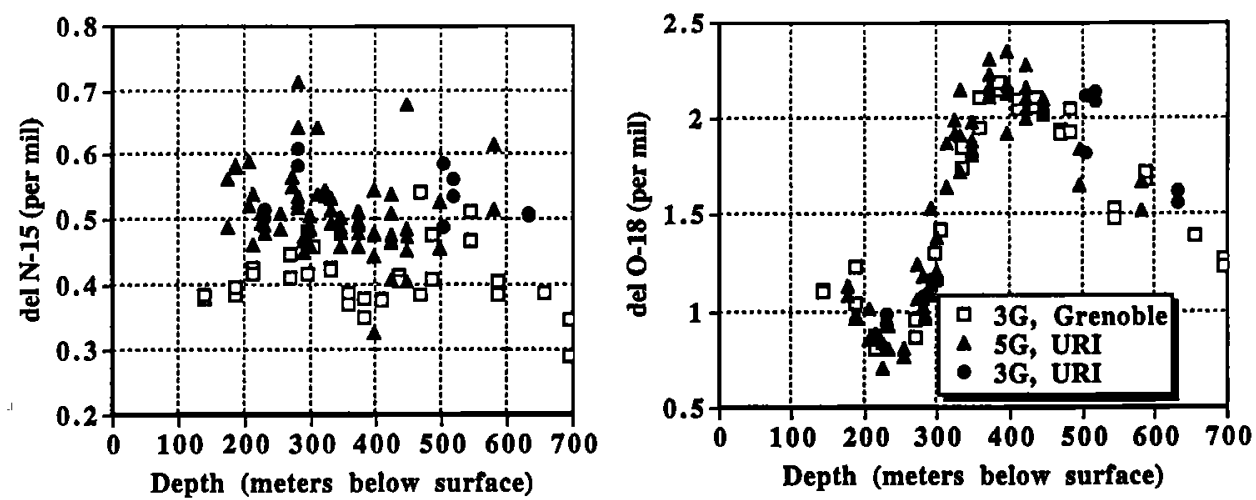

Figure 3. $\delta^{15} \mathrm{~N}$ of $\mathrm{N}_{2}$ and $\delta^{18} \mathrm{O}$ of $\mathrm{O}_{2}$ versus depth in Vostok ice cores for samples from the 3G core extracted in Grenoble, the $3 \mathrm{G}$ core extracted at URI, and the $5 \mathrm{G}$ core extracted at URI. $\delta^{18} \mathrm{O}$ values agree well but $\delta^{15} \mathrm{~N}$ values are offset by $0.1 \%$ between samples extracted in Grenoble and samples extracted at URI. For reference, nominal ice ages are $7.4 \mathrm{kyr}$ at $200 \mathrm{~m}, 25 \mathrm{kyr}$ at $400 \mathrm{~m}$, and $42 \mathrm{kyr}$ at $600 \mathrm{~m}$ depth. 
very near to its present value. $\Delta$ Dole effect reaches a maximum at $\sim 13 \mathrm{kyr} B$. $P$ and a minimum at $\sim 8 \mathrm{kyr} B$. $P$. Until about $11 \mathrm{kyr} B . \mathrm{P}, \delta^{18} \mathrm{O}_{\mathrm{atm}}$ data are very close to the curve denoting constant biogeochemical fractionation. The $\Delta$ Dole effect maximum at $13 \mathrm{kyr}$ BP may largely reflect the $1.2 \mathrm{kyr}$ turnover time of atmospheric $\mathrm{O}_{2}$ and the associated lag in the response of $\delta^{18} \mathrm{O}_{\mathrm{atm}}$ to changes in $\delta^{18} \mathrm{O}_{\mathrm{sw}}$. On the other hand, the minimum at about $8 \mathrm{kyr}$ B. P. is undoubtedly due to changing isotope fractionations associated with transient processes of the biosphere and hydrosphere. This minimum in $\Delta$ Dole effect may be related to the inferred maximum in lowlatitude precipitation at $\sim 10 \mathrm{kyr} \mathrm{B}$. P. and the intensification of the monsoon at this time [Prell and Kutzbach, 1987], reforestation of the temperate northern hemisphere and the associated minimum in atmospheric $\mathrm{pCO}_{2}$ [Neftel et al., 1988], and/or to transients in oceanic circulation and productivity at the end of the last ice age.

\section{Vostok Record}

$\Delta$ Dole effect calculated for Vostok is plotted versus age, along with average June insolation at $20^{\circ} \mathrm{N}$, in Figure $4 \mathrm{a}$.

$\Delta$ Dole effect varies with the 23-kyr precession cycle (Table 2). This periodicity is reflected in maxima in the Dole effect at about 128 - $133 \mathrm{kyr}, 108 \mathrm{kyr}, 84-91 \mathrm{kyr}, 58 \mathrm{kyr}, 35 \mathrm{kyr}, 25$ $\mathrm{kyr}$, and $13 \mathrm{kyr} \mathrm{B}$. P. The $25-\mathrm{kyr}$ maximum in $\Delta$ Dole effect is anomalous, because it does not correspond to a maximum in insolation. However, it would disappear if the age assigned to the $\delta^{18} \mathrm{O}_{\mathrm{atm}}$ minimum at $30 \mathrm{kyr}$ were decreased by about $4 \mathrm{kyr}$ to align the minimum with the $\delta^{18} \mathrm{O}_{\mathrm{sw}}$ minimum at $26 \mathrm{kyr}$ [Sowers et al., 1993]. Such a change would also bring the chronology of Sowers et al. into better agreement with other chronologies proposed for the Vostok ice core during this time period. At the present time, we merely note that sample resolution between 25 and $47 \mathrm{kyr}$ in the Vostok ice core is not good enough to generate a reliable chronology based on $\delta^{18} \mathrm{O}_{\text {atm }}$ alone.

Variations of $\Delta$ Dole effect, as calculated from the Sowers et al. [1993] chronology, are highly coherent with, and nearly in phase with, insolation. The phasing is similar to that observed in the GISP2 record. Maxima in $\triangle$ Dole effect occur at times of maximum insolation. Minima in $\Delta D$ ole effect lead minima in insolation (at $100 \mathrm{kyr}, 77 \mathrm{kyr}$, and $7 \mathrm{kyr}$ ) or occur in phase (115 kyr, $46 \mathrm{kyr}$ ). At the time of termination II, variations in $\Delta$ Dole effect may largely reflect the $1.2-\mathrm{kyr}$ turnover time of $\mathrm{O}_{2}$ in air, as for GISP2 (see above). However, for other events the coincidence of the $\Delta$ Dole effect maxima with respect to insolation cannot be due to the lag in the atmospheric response. The reason for this is that the change in $\delta^{18} \mathrm{O}_{\mathrm{sw}}$ is too small, and the calculated atmospheric response is too rapid, to induce a change of the magnitude observed. At times other than the terminations, variability in $\Delta$ Dole effect must either be biogeochemical or an artifact of the chronology.

Unfortunately, errors in the chronology of Vostok with respect to SPECMAP can induce very large changes in apparent values of $\triangle$ Dole effect. We illustrate this with Figures $4 b$ and $4 c$. In Figure $4 b$ we plot $\Delta$ Dole effect after holding the chronology of SPECMAP constant but decreasing all Vostok ages by $3 \mathrm{kyr}$. This change in the chronology of Vostok reduces noise and greatly increases the coherency
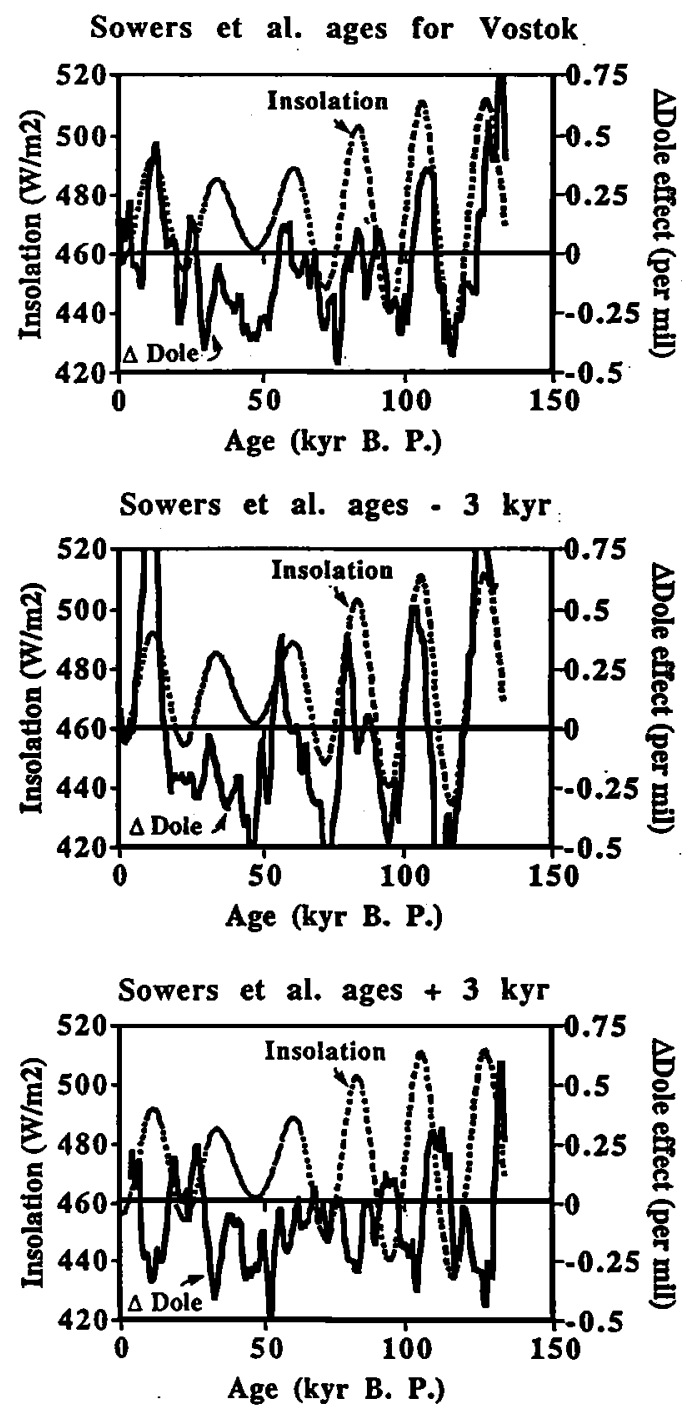

Figure 4. $\triangle$ Dole effect and integrated June insolation versus SPECMAP age at $20^{\circ} \mathrm{N}$. (a) Sowers et al. [1993] chronology for $\delta^{18} \mathrm{O}_{\text {atm }}$ (Vostok) versus age, (b) $3 \mathrm{kyr}$ subtracted from Sowers et al. age, (c) $3 \mathrm{kyr}$ added to Sowers et al. age. The SPECMAP chronology is used throughout for the $\delta^{18} \mathrm{O}_{\text {sw }}$ curve. This figure illustrates the high coherency between $\Delta$ Dole effect and insolation for the Sowers et al. chronology but also shows that the calculated values of $\Delta$ Dole effect are rather sensitive to relative errors in the ages of the Vostok and SPECMAP records.

between $\Delta$ Dole effect and insolation (Table 2b). In Figure $4 c$ we calculate $\Delta$ Dole effect after holding the chronology of SPECMAP constant but increasing all Vostok ages by $3 \mathrm{kyr}$. This change in the Vostok chronology adds a great deal of noise to the $\Delta$ Dole record, reduces the coherency between $\Delta$ Dole and insolation (Table 2), and changes the phase by about $130^{\circ}$ (Table 2). The coherent nature of the $\Delta$ Dole effect and insolation curves is robust, suggesting that changes in the Dole effect are related to insolation variations. However, we do not yet understand the chronology of Vostok well enough to determine phase differences between $\Delta$ Dole effect and other climate variables. 
Table 2a. Spectral Analysis

\begin{tabular}{lcc}
\hline Variable & Period, kyr & f statistic \\
\hline \multirow{2}{*}{ Dole effect } & 22.8 & 0.93 \\
\multirow{2}{*}{$\mathrm{CH}_{4}$} & 13.2 & 0.84 \\
& 13.6 & 0.85 \\
$\delta^{18} \mathrm{O}_{\text {atm }}$ & 22.3 & 0.99 \\
& 14.5 & 0.93 \\
& 41.8 & 0.92 \\
& 21.6 & 0.93 \\
& 18.1 & 0.81 \\
\hline
\end{tabular}

Analyses were run using the multi-taper method. Results are given only for frequencies where the f-statistic was greater than 0.8 .

\section{Table 2b. Cross Spectral Analysis}

\begin{tabular}{|c|c|c|c|}
\hline Variables & Period, kyr & Coherency & Phase,kyr \\
\hline $\mathrm{CH}_{4}-\Delta$ Dole effect & 21.5 & 0.82 & $\begin{array}{c}5.1 \\
\left(\mathrm{CH}_{4} \text { leads }\right)\end{array}$ \\
\hline$\Delta$ Dole-insolation & 22.1 & 0.92 & (insolation leads) \\
\hline $\begin{array}{l}\triangle \text { Dole-insolation; } \\
\text { subtract } 3 \mathrm{kyr} \text { fro } \\
\text { SPECMAP gas ag }\end{array}$ & $\begin{array}{l}20.6 \\
\text { om }\end{array}$ & 0.96 & $\begin{array}{c}1 \\
\text { ( } \Delta \text { Dole leads) }\end{array}$ \\
\hline $\begin{array}{l}\Delta \text {-insolation; } \\
\text { add } 3 \mathrm{kyr} \text { to } \\
\text { gas age }\end{array}$ & 19.4 & 0.79 & $\begin{array}{c}7 \\
\text { (insolation leads) }\end{array}$ \\
\hline
\end{tabular}

Cross spectral analyses run using the Blackman-Tuckey method.

Results are given only when the coherency was greater than 0.8 .

"Insolation" refers to average June insolation at $20^{\circ} \mathrm{N}$.

\section{Why Does $\Delta$ Dole Effect Vary With the Periodicity of Precession?}

Most variability in insolation at low latitudes is associated with precession, while at high latitudes tilt also becomes important. The strong precession signal in $\Delta$ Dole effect suggests that variations in the Dole effect are probably linked to low latitude processes. There are strong precession signals in both marine and continental proxy records from low latitudes (e. g., Clemens and Prell, 1990; Chappellaz et al., 1990). In principle, we could use the phasing of proxy signals and $\Delta$ Dole effect to test whether certain climate variables influence $\Delta$ Dole effect. For example, if low-latitude ocean productivity changes were driving changes in the Dole effect, we would expect these two records to be about $180^{\circ}$ out of phase (high oceanic productivity leads to lower Dole effect). In practice, we do not know phasing well enough to use this criterion.
Most marine proxy records show variability in the precession band [e. g., Imbrie et al., 1992], but those showing dominant variability in the precession band are rare during the late Pleistocene due to the predominant influence of the ice sheets on glacial - interglacial climate cycles with their associated obliquity signal. They are restricted to the equatorial Atlantic [McIntyre et al., 1989; Molfino and McIntyre, 1990] and the equatorial Indian Oceans [Clemens and Prell, 1990]. It seems possible but unlikely that variability of primary productivity in these restricted areas of the ocean would have dominated changes in the Dole effect. We therefore look to changes in the continental biosphere to explain variations in the Dole effect.

The $\mathrm{CH}_{4}$ concentration is the simplest indicator of largescale variations in the continental biosphere. $\mathrm{CH}_{4}$ variations during the last $150 \mathrm{kyr}$ B. P., measured in the Vostok ice core by Chappellaz et al. [1990], vary by a factor of 2, with most variability concentrated in the precession band. Chappellaz et al. [1990] linked $\mathrm{CH}_{4}$ maxima to maxima in paleoprecipitation as estimated by Prell and Kutzbach [1987]. The connection results from the fact that precipitation is linked to evaporation at low latitudes and therefore to insolation. Increased precipitation stimulates the activity of the biosphere, particularly in wetlands which are the major $\mathrm{CH}_{4}$ source.

Increased precipitation would also cause the Dole effect to change, because continental productivity would increase and the leaf water enrichment would vary. The effect of increased terrestrial production would be to raise the Dole effect by increasing the production rate of ${ }^{18} \mathrm{O}$ - enriched photosynthetic $\mathrm{O}_{2}$ coming from the land biosphere. The effect of increased wetness and humidity is to lower the Dole effect by diminishing the leaf water enrichment. The phasing between insolation and the Dole effect is unclear. Improved chronologies for deep-sea sediments, together with modeling studies of terrestrial productivity and leaf water enrichments such as those of Farquhar et al. [1993], will allow us to improve our record of past changes in the Dole effect and our understanding of their biogeochemical implications.

\section{Why is Variability in the Dole Effect so Small?}

As shown above, $\Delta$ Dole effect varies with a period of $\sim 23$ kyr, suggesting a response by the low-latitude biosphere linked to insolation changes induced by precession. This periodicity not withstanding, $\Delta$ Dole effect has been remarkably constant. The mean and standard deviation, based on Vostok, has been - $0.05 \%$ $\pm 0.24 \%$, as calculated from our record interpolated to $0.5 \mathrm{kyr}$ intervals.

Even more striking is the similarity of the Dole effect between glacial and interglacial times. The $\Delta$ Dole effect during the last glacial maximum was close to $0 \%$ (Figures 2 and $4 a)$. The change in $\Delta$ Dole effect between the penultimate glacial maximum (stage 6) and the last interglacial (stage 5e) was also very small: $\delta^{18} \mathrm{O}_{\text {sw }}$ decreased by $\sim 1.2 \%$ during the termination, and $\delta^{18} \mathrm{O}_{\text {atm }}$ decreased by $\sim 1.4 \%$ (Figure $4 \mathrm{a}$ ) [Sowers et al., 1991]. There may indeed have been a large change in $\Delta$ Dole effect during termination II similar to the change we observed during termination I (Figure 4a). However, between full glacial and full interglacial climates the 
change in the Dole effect was very small, despite the drastic changes in the water cycle and biogeography. Why has the Dole effect been so constant?

Answering this question is impossible at the present time, but we can probably recognize the key influences. The influence of the land biosphere during glacial times would have been different from that today in the following ways:

1. During glacial times, climate was colder and drier and $\mathrm{pCO}_{2}$ was lower. Much of the temperate and polar regions were covered by ice. Cold climate, low precipitation, and extensive ice cover would all lower glacial productivity; Meyer [1988] has estimated that terrestrial net primary production during the last glacial maximum (LGM) was $\sim 75 \%$ of the present value. If everything else were constant, this change would have lowered the rate of photosynthesis by the land biosphere and hence the Dole effect.

2. Drier climates probably would have caused more extensive leaf water fractionation, which would cause the Dole effect to rise.

3. Meyer's estimates of production during the LGM do not include the influence of lower atmospheric $\mathrm{CO}_{2}$ on glacial productivity. If production varies by $\mathrm{CO}_{2}{ }^{0.3}$ [Keeling et al., 1989], glacial productivity on land would have decreased by an additional factor of $(180 \mathrm{ppmV} / 280 \mathrm{ppmV})^{0.3}$, or 0.88 , further lowering the Dole effect. The true effect of lower $\mathrm{CO}_{2}$ would be much less if nutrients ultimately limit production.

4. The lower $\mathrm{CO}_{2}$ concentration in air during the last glacial period would have caused the ratio of photorespiration/carboxylation $(\phi)$ to increase from a calculated preindustrial value of 0.31-0.48 during the LGM, according to (2). On the other hand, the colder glacial temperatures would have caused $\phi$ to decrease by a factor of 0.88. This value is calculated taking $Q 10$ for the ratio of oxidation to carboxylation to be 0.57 [Collatz et al., 1991]. Overall, we expect $\phi$ to have risen from a calculated preindustrial value of 0.31-0.42 during the LGM. Other things being equal, this increase in $\phi$ would have caused the Dole effect to rise for two reasons. First, it heralds an increase in terrestrial gross production, which raises the Dole effect because of the leaf water enrichment. Second, there is a relatively large isotope effect associated with photorespiration.

On the marine side, isotope discrimination probably was similar during the LGM and today. Changes in the oceanic contribution to the Dole effect would have come from changes in marine production. Oceanic production during the LGM differed from that of today in two ways:

1. A number of studies have examined the fertility of the deep oceans during the last glacial maximum. The most ambitious of these are the studies using sedimentary organic carbon accumulation rates [e. g., Sarnthein et al., 1988] and foraminiferal transfer functions [e. g., Mix, 1989a, b]. The former approach has given contradictory results in different oceanic areas (hardly surprising, since there is no reason to suspect that productivity would change uniformly throughout the ocean), but has generally indicated higher glacial values [Sarnthein et al., 1988]. The same is true of the transfer function approach in the Atlantic [Mix, 1989a]. On average, both approaches indicate higher deep ocean productivity during the last glacial maximum. However, we note that neither approach is free of problems, and results from these two approaches are not mutually consistent, sometimes

\section{Table 3. Literature Estimates of Paleoproductivity During the Last Glacial} Maximum

\begin{tabular}{llc}
\hline Citation & Study region & Paleoproductivity \\
\hline $\begin{array}{l}\text { Sarnthein } \text { et al. }[1988] \\
\text { Marino et al. }[1992]\end{array}$ & $\begin{array}{l}\text { Global } \\
\text { Global }\end{array}$ & Lower in polar ocean, higher elsewhere
\end{tabular}

Equatorial Pacific

Thunnell et al. [1992]

Archer [1991]

Lyle [1988]

Pedersen et al. [1991]

Lyle et al. [1992]

Oregon Coast

Dymond et al. [1992]

Atlantic Ocean

Mix [1989a]

Molfino and McIntyre [1990]

Lyle [1988]
South China Sea

Central equatorial Pacific

Equatorial Pacific

Eastern equatorial Pacific

Central equatorial Pacific

Entire Atlantic Ocean

Equatorial Atlantic

$$
\begin{aligned}
& 2 \\
& \sim 2 \\
& >1 \\
& \sim 3
\end{aligned}(\sim 2 ?)
$$

Glacial upwelling more intense

$$
0.5
$$

Glacial upwelling more intense $>1(-2 ?)$
Southern Ocean

Charles et al. [1991]

Atlantic and Indian regions

$\sim 1$ but

meridionally variable 
giving downcore variations of production that are very different in magnitude [e. g., Sarnthein et al., 1992, Figures 3, 4, and 6], which are uncorrelated within individual cores [Sarnthein et al., 1992, Figure 7], or which are anticorrelated over long depth intervals [Mix, 1989b]. A wide range of other approaches has been used to estimate paleoproductivity during the last glacial maximum. Results, summarized in Table 3, are unanimous in concluding that equatorial Pacific productivity was higher during the last glacial maximum. Elsewhere, the sense of productivity variations differed from one region to another. However, the general sense is that open ocean production was higher during the last glacial maximum. This would cause a drop in the Dole effect.

2. The continental shelves, which are highly productive, account for $\sim 7 \%$ of the area of the sea floor and $\sim 20 \%$ of total oceanic production [Walsh, 1991]. During glacial times, most of the shelf area would have been exposed and would thus not have contributed to oceanic production. In addition, production on the shallow part of the continental slope would have been suppressed by extensive sea ice cover in the Arctic and Antarctic and by isostatic depression of the landward portion of the continental slope bordering glaciated areas. These processes would have cause global ocean productivity to fall and the Dole effect to rise.

In summary, we can conclude that the Dole effect has been rather constant during the last $130 \mathrm{kyr}$ because environmental changes have induced roughly offsetting changes in oxygen isotope fractionation of $\mathrm{O}_{2}$. We can recognize the nature of these changes, but we cannot account quantitatively for their varying influence on the Dole effect.

\section{Summary and Conclusions}

Our ability to explain the magnitude of the contemporary Dole effect is a measure of our understanding of the global cycles of oxygen and water. A variety of recent studies have improved our understanding of many of the principles governing oxygen isotope fractionation during photosynthesis and respiration, of production rates on land and in the oceans, and of the effect of stratospheric photochemistry on the $\delta^{18} \mathrm{O}$ of $\mathrm{O}_{2}$ in air. However, our attempt to quantitatively account for the Dole effect in terms of these principles was not very successful: We estimated the presentday Dole effect to be $+20.8 \%$ compared to the observed value of $+23.5 \%$. The agreement is considerably worse than it might appear given the fact that respiratory isotope fractionation alone must account for $\sim 20 \%$ of the stationary enrichment of the ${ }^{18} \mathrm{O}$ of $\mathrm{O}_{2}$ compared with seawater. Our underestimate of the true magnitude most likely reflects an underestimate in the leaf water enrichment, failure to consider respiration by the alternative (cyanide resistant) pathway, and perhaps an overestimate of marine production.

We have used data on the $\delta^{18} \mathrm{O}$ of $\mathrm{O}_{2}$ from the Vostok ice core to calculate changes in the Dole effect during the last 130 kyr. Our results show that variations in the Dole effect have been relatively small during most of the last glacial interglacial cycle. These small changes are not consistent with large glacial increases in global oceanic productivity. Changes in the Dole effect vary with the period of precession, and we conclude that they largely reflect changes in terrestrial productivity and leaf water fractionation associated with variations in humidity and tropical precipitation.

Acknowledgments. This research was supported by the Office of Polar Programs, U. S. National Science Foundation, and PNEDC, France. Graham Farquhar, Jean Jouzel, Dominique Raynaud, Joseph Berry, Mark Thiemens, and Steven Emerson discussed ideas in the paper with us. M. B. happily acknowledges generous support from C. N. R. S. and C. E. A., France, during his sabbatical at Centre des Faibles Radioactivites.

\section{References}

Alley, R. B., D. Meese, C. A. Shuman, A. J. Gow, K. Taylor, M. Ram, E. Waddington, J. W. C. White and P. Mayewski, Abrupt accumulation increase at the Younger Dryas termination in the GISP2 ice core, Nature, 362, 527-529, 1993.

Archer, D., Equatorial Pacific calcite preservation cycles: Production or dissolution?, Paleoceanography, 6, 561-571, 1991.

Bender, M., The $\delta^{18} \mathrm{O}$ of dissolved $\mathrm{O}_{2}$ in seawater: $\mathrm{S}$ unique tracer of circulation and respiration in the deep sea, J. Geophys. Res., 95, 22,243-22,252, 1990.

Bender, M., L. Labeyrie, D. Raynaud, and C. Lorius, Isotopic composition of atmospheric $\mathrm{O}_{2}$ in ice linked with deglaciation and global primary productivity, Nature, 318, 349-352, 1985.

Benson, B., and D. Krause, Jr., The concentration and isotopic fractionation of oxygen dissolved in fresh water and seawater in equilibrium with the atmosphere, Limnol. Oceanogr., 29, 620-632, 1984.

Berry, J., Biosphere, atmosphere, ocean interactions: A plant physiologist's perspective, in Primary Productivity and Biogeochemical Cycles in the Sea, edited by P. G. Falkowski and A. D. Woodhead, pp. 441-454, Plenum, New York, 1992.

Boyle, E., The role of vertical chemical fractionation in controlling Late Quaternary atmospheric carbon dioxide, J. Geophys. Res., 93, 15,701-15,715, 1988.

Broecker, W. S., The cause of the glacial to interglacial atmospheric $\mathrm{CO}_{2}$ change: A polar alkalinity hypothesis, Global Biogeochem. Cycles, 3, 215-239, 1989.

Chappellaz, J., J. M. Barnola, D. Raynaud, Y. S. Korotkevich, and C. Lorius, Ice core record of atmospheric methane over the past 160,000 years, Nature, 345, 127-131, 1990.

Charles, C. D., P. N. Froelich, M. A. Zibello, R. A. Mortlock, and J. J. Morley, Biogenic opal in southern ocean sediments over the last 450,000 years: Implications for surface water chemistry and circulation, Paleoceanography, 6, 697-728, 1991.

Clemens, S., and W. Prell, Late Pleistocene variability of Arabian sea summer monsoon winds and continental aridity: Eolian records from the lithogenic component of deep-sea sediments, Paleoceanography, $5,109-145,1990$.

COHMAP members, Climatic changes of the last 18,000 years: Observations and model simulations, Science, 241, 1043-1052, 1988.

Collatz, G. T., J. T. Ball, C. Grivet, and J. A. Berry, Physiological and environmental regulation of stomatal conductance, photosynthesis and transpiration: A model that includes a laminar boundary layer, Agric. and For. Meteorol., 54, 107-136, 1991.

Craig, H. and L. Gordon, Deuterium and oxygen- 18 variation in the ocean and marine atmosphere. paper presented at Conference on Stable Isotopes in Oceanography, International Atomic Energy Agency, Pisa, 1965.

Craig, H., Y. Horibe, and T. A. Sowers, Gravitational separation of gases and isotopes in polar ice caps, Science, 242, 1675-1678, 1988.

Dole, M., G. Lane, D. Rudd, and D. A. Zaukelies, Isotopic composition of atmospheric oxygen and nitrogen, Geochim. Cosmochim. Acta, 6, 65-78, 1954.

Dongmann, G., The contribution of land photosynthesis to the stationary 
enrichment of ${ }^{18} \mathrm{O}$ in the atmosphere, Radiat.Environ. Biophys., 11 , 219-225, 1974.

Dongmann, G., H. W. Nurnberg, H. Forstel and K. Wagener, On the Enrichment of $\mathrm{H}_{2}{ }^{18} \mathrm{O}$ in the leaves of transpiring plants, Radiat. Environ. Biophys., 11, 41-52, 1974.

Dymond, J., E. Suess, and M. Lyle, Barium in deep-sea sediment: A geochemical proxy for paleoproductivity, Paleoceanography, 7, 163$181,1992$.

Epstein, S., and L. Zeiri, Oxygen and carbon isotopic composition of gases respired by humans, Proc. Natl. Acad. Sci. U. S. A., 85, 1727$1731,1988$.

Farquhar, G. D., S. von Caemmerer, and J. A. Berry, A biochemical model of photosynthetic $\mathrm{CO}_{2}$ assimilation in leaves of $\mathrm{C}_{3}$ species, Planta, 149, 78-90, 1980.

Farquhar, G. D., J. Lloyd, J. A. Taylor, L. Flanagan, J. P. Syvertsen, K. T. Hubick, S. Wong, and J. R. Ehleringer, Vegetation effects on the isotope composition of oxygen in atmospheric $\mathrm{CO}_{2}$, Nature, 363, 439$443,1993$.

Farris, F. and B. R. Strain, The effects of water-stress on leaf $\mathrm{H}_{2}{ }^{18} \mathrm{O}$ enrichment, Rad. and Environm. Biophys., 15, 167-202, 1978.

Forstel, H., The enrichment of ${ }^{18} \mathrm{O}$ in leaf water under natural conditions, Radiat. Environ. Biophys., 15, 323-344, 1978.

Gamo, T., M. Tsutsumi, H. Sakai, T. Nakazawa, M. Tanaka, H. Honda, $\mathrm{H}$. Kubo, and T. Itoh, Carbon and oxygen isotopic ratios of carbon dioxide of a stratospheric profile over Japan, Tellus, 41B, 127-133, 1989.

Guy, R. D., J. A. Berry, M. L. Fogel and T. C. Hoering, Differential fractionation of oxygen isotopes by cyanide-resistant and cyanidesensitive respiration in plants, Planta, 177, 483-491, 1989.

Guy, R. D., J. A. Berry, M. L. Fogel, D. H. Turpin and H. G. Weger, Fractionation of the stable isotopes of oxygen during respiration by plants-The basis of a new technique to estimate partitioning to the alternative path, in Biochemical and Physiological Aspects of Plant Respiration, edited by H. Lambers and L. H. W. van der Plas, pp. 443-453, SPB Academic Publishing, The Hague, Netherlands, 1992.

Guy, R. D., M. L. Fogel, and J. A. Berry, Photosynthetic fractionation of stable isotopes, Plant Physiol, 101, 37-47, 1993.

Horibe, Y., K. Shigehara, and C. C. Langway Jr., Chemical and isotopic composition of air in a Greenland ice core, Earth Planet. Sci. Lett., 73, 207-210, 1985.

Imbrie, J., et al., On the structure and origin of major glaciation cycles, 1, Linear responses to Milankovitch Forcing, Paleoceanography, 7, 701-738, 1992.

Keeling, C. D., R. B. Bacastow, A. R. Carter, S. C. Piper, T. P. Whorf, M. Heimann, W. Mook, and H. Roeloffzen, A three-dimensional model of atmospheric $\mathrm{CO}_{2}$ transport based on observed winds: 1 . Analysis of observational data, in Aspects of Climate Variability in the Pacific and the Western Americas, Geophys. Monogr. Ser. Vol. 55, edited by D. H. Peterson, pp. 165-236, American Geophysical Union, Washington, D. C., 1989.

Keeling, R., and S. Shertz, Seasonal and interannual variations in atmospheric oxygen and implications for the global carbon cycle, Nature, 358, 723-727, 1992.

Kiddon, J., M. Bender, J. Orchardo, J. Goldman, D. Caron, and M. Dennett, Isotopic fractionation of oxygen by respiring marine organisms, Global Biogeochem. Cycles, 7, 679-694, 1993.

Knox, F., and M. McElroy, Changes in atmospheric $\mathrm{CO}_{2}$; influence of marine biota at high latitudes, J. Geophys. Res., 89, 4629-2637, 1984.

Kroopnick, P. M., Oxygen 18 in dissolved oxygen, in Geosecs Atlantic, Pacific, and Indian Ocean Expeditions: Shorebased Data and Graphics, Vol. 7, edited by H. G. Ostlund, H. Craig, W. S. Broecker, and D. Spencer, pp. 3 and 27-182, U. S. Government Printing Office, Washington, D. C., 1987.

Kroopnick, P., and H. Craig, Atmospheric oxygen: Isotopic composition and solubility fractionation, Science, 175, 54-55,1972.

Kroopnick, P., and H. Craig, Oxygen isotope fractionation in dissolved oxygen in the deep sea, Earth Planet. Sci. Lett., 32 , 375-388, 1976.
Lane, G., and M. Dole, Fractionation of oxygen isotopes during respiration, Science, 123, 574-576, 1956.

Lyle, M., Climatically forced organic carbon burial in equatorial Atlantic and Pacific Oceans, Nature, 335, 529-532, 1988.

Lyle, M. W., F. G. Prahl, and M. A. Sparrow, Upwelling and productivity changes inferred from a temperature record in the central equatorial Pacific, Nature, 355, 812-815, 1992.

Malaize, Bruno, thesis.

Marino, B, M. McElroy, R. Salawitch, and W. Spaulding, Glacial-tointerglacial variations in the carbon isotopic composition of atmospheric $\mathrm{CO}_{2}$, Nature, 357, 461-466, 1992.

Martinson, D. G., W. Menke, and P. Stoffa, An inverse approach to signal correlation, J. Geophys. Res., 87, 4807-4818, 1982.

McIntyre, A., W. Ruddiman, K. Karlin, and A. Mix, Surface water response of the equatorial Atlantic Ocean to orbital forcing, Paleoceanography, 4, 19-55,1989.

Meyer, M. K., Net primary productivity estimates for the last 18,000 years evaluated from simulations by a global climate model, M. S. dissertation, Univ. of Wis. Madison, 1988.

Mix, A., Productivity of the Pleistocene Atlantic ocean estimated from foraminiferal species: Implications for paleo- $\mathrm{pCO}_{2}$, Nature, 337, 541-544, 1989a.

Mix, A., Pleistocene paleoproductivity: Evidence from organic carbon and foraminiferal species, in Productivity of the Ocean: Present and Past, edited by W. H. Berger, V. Smetacek, and G. Wefer, John Wiley, New York,1989b.

Molfino, B. and A. McIntyre, Precessional forcing of nutricline dynamics in the equatorial Atlantic, Science, 249, 766-769,1990.

Neftel, A., H. Oeschger, T. Staffelbach, and B. Stauffer, $\mathrm{CO}_{2}$ record in the Byrd ice core 50,000-5,000 years BP, Nature, 331, 609-611, 1988.

Pedersen, T. F., B. Nielsen, and M. Pickering, Timing of late Quaternary productivity pulses in the Panama Basin and implications for atmospheric $\mathrm{CO}_{2}$, Paleoceanography, 6, 657-677, 1991.

Prell, W. L. and J. E. Kutzbach, Monsoon variability over the past 150,000 years, J. Geophys. Res., 92, 8411-8425, 1987.

Sarnthein, M., K. Winn, J.-C. Duplessy, and M. R. Fontugne, Global variations of surface ocean productivity in low and mid latitudes: influence on $\mathrm{CO}_{2}$ reservoirs of the deep ocean and atmosphere during the last 21,000 years, Paleoceanography, 3, 361-399, 1988.

Sarnthein, M., U. Pflaumann, R. Ross, R. Tiedemann, and K. Winn, Transfer functions to reconstruct ocean paleoproductivity: a comparison, Geol. Soc. London, 63, 411-427, 1992.

Schmidt, U., and A. Khedim, In situ measurements of carbon dioxide in the winter Arctic vortex and at midlatitudes: An indicator of the 'age' of stratospheric air, Geophys. Res. Lett., 18, 763-766, 1991.

Shackleton, N. J., and N. G. Pisias, Atmospheric carbon dioxide, orbital forcing, and climate, in The Carbon Cycle and Atmospheric $\mathrm{CO}_{2}$ : Natural Variations Archean to Present, Geophys. Monogr. Ser., Vol. 32, edited by E. T. Sundquist and W. S. Broecker, pp. 303-317, AGU, Washington, D. C., 1985.

Sowers, T., M. Bender, D. Raynaud, Y. S. Korotkevich, and J. Orchardo, The $\delta^{18} \mathrm{O}$ of atmospheric $\mathrm{O}_{2}$ from air inclusions in the Vostok ice core: Timing of $\mathrm{CO}_{2}$ and ice volume changes during the penultimate deglaciation, Paleoceanography, 6, 679-696, 1991.

Sowers, T., M. Bender, L. Labeyrie, D. Martinson, J. Jouzel, D. Raynaud, and Y. S. Korotkevich, 135,000 year Vostok - SPECMAP common temporal framework, Paleoceanography, 8, 737-766, 1993.

Stevens, C., R. Schultz, C. Van Baalen, and P. Parker, Oxygen isotope fractionation during photosynthesis in a blue-green and a green alga, Plant Physiol., 56, 126-129, 1975.

Thiemens, M., T. Jackson, K. Mauersberger, B. Schueler, and J. Morton, Oxygen isotope fractionation in stratospheric $\mathrm{CO}_{2}$, Geophys. Res. Lett., 18, 669-672, 1991.

Thunell, R. C., M. Qingmin, S. Calvert and T. F. Pedersen, GlacialHolocene biogenic sedimentation patterns in the south China Sea: 
Productivity variations and surface water $\mathrm{pCO}_{2}$, Paleoceanography, 7, 143-162, 1992.

Walsh, J. J., Importance of continental margins in the marine biogeochemical cycling of carbon and nitrogen, Nature, 350, 53-55, 1991.

Wen, J., and M. H. Thiemens, First multi-isotope study of the $O\left({ }^{1} D\right)+$ $\mathrm{CO}_{2}$ exchange and stratospheric consequences. J. Geophys. Res., 98, 12,801-12,808, 1993.

Yakir, D., M. DeNiro, and P. Rundel, Isotopic inhomogeneity of leaf water: Evidence and implications for the use of isotopic signals transduced by plants, Geochim. Cosmochim. Acta, 53, 2769-2773, 1989.

Yung, Y., W. De Mone, and J. P. Pinto, Isotopic exchange between carbon dioxide and ozone via $\mathrm{O}\left({ }^{1} \mathrm{D}\right)$ in the stratosphere, Geophys. Res. Lett., 18, 13-16, 1991.
Zundel, G., W. Miekeley, B. M. Grisi, and H. Forstel, The $\mathrm{H}_{2}{ }^{18} \mathrm{O}$ enrichment in the leaf water of tropic trees: comparison of species from the tropical rain forest and the semi-arid region in Brazil, Radiat. Environ. Biophys., 15, 203-212, 1978.

M. Bender and T. Sowers, Graduate School of Oceanography, University of Rhode Island, Kingston, RI 02881.

L. Labeyrie, Centre des Faibles Radioactivites, CNRS-CEA, Domaine du CNRS, 91190 Gif-sur-Yvette, France.

(Received July 22, 1993; revised February 7, 1994; accepted March 11, 1994.) 